Annivesary

Ювілеї
ISSN: 2411-6181(on-line); ISSN: 2311-9896 (print)

Current issues of social studies and history of medicine. Joint Ukrainian

-Romanian scientific journal, 2019, №:4 (24), P. 44-48

UDK 061:61(477)

DOI 10.24061/2411-6181.4.2019.149

З КОГОРТИ ЗАХОПЛЕНИХ НАУКОЮ ТА

НАВЧАЛЬНО-ПЕДАГОГІЧНОЮ ДІЯЛЬНІСТЮ:

ДО 75-РІЧЧЯ КОЧІНА ІГОРЯ ВАСИЛЬОВИЧА

Антоній МОЙСЕЙ,

ВДНЗ України "Буковинський державний медичний

університет", Чернівці (Україна)

antoniimoisei@bsmu.edu.ua

\title{
ONE OF PEOPLE, WHO IS FOND OF SCIENCE AND \\ EDUCATIONAL ACTIVITIES: DEDICATED MATERIAL TO THE 75-ANNIVESARY OF KOCHIN IGOR VASYLYOVYCH \\ Antoniy MOYSEY, \\ Higher State Educational Establishment of Ukraine \\ «Bukovinian State Medical University», Chernivtsi (Ukraine), \\ ORCID ID: 0000-0001-5295-2271; Researcher ID: S-5261-2016
}

Мойсей Антоний. Из людей, истинно увлеченных наукой и учебно-педагогической деятельностью: к 75-летию Кочина Игоря Васильевича. В статье освещены биографические вехи и научные достижения известного украинского ученого, заведующего кафедрой гражданской защиты и медицины катастроф Государственного учреждения «Запорожская медицинская академия последипломного образования МЗ Украины», доктор медицинских наук, доктора философии, профессора, академика Украинской международной академии оригинальных идей, председателя научно-методического совета по вопросам гражданской защиты и безопасности жизнедеятельности населения Запорожской области, заместителя атамана Союза общественных организаций «Запорожский казацкий округ», генерал-хорунжего Войска Запорожского Низового.

Ключевые слова: Кочин Игорь Васильевич, Запорожская медицинская академия последипломного образования МЗ Украины, биографическое исследование.

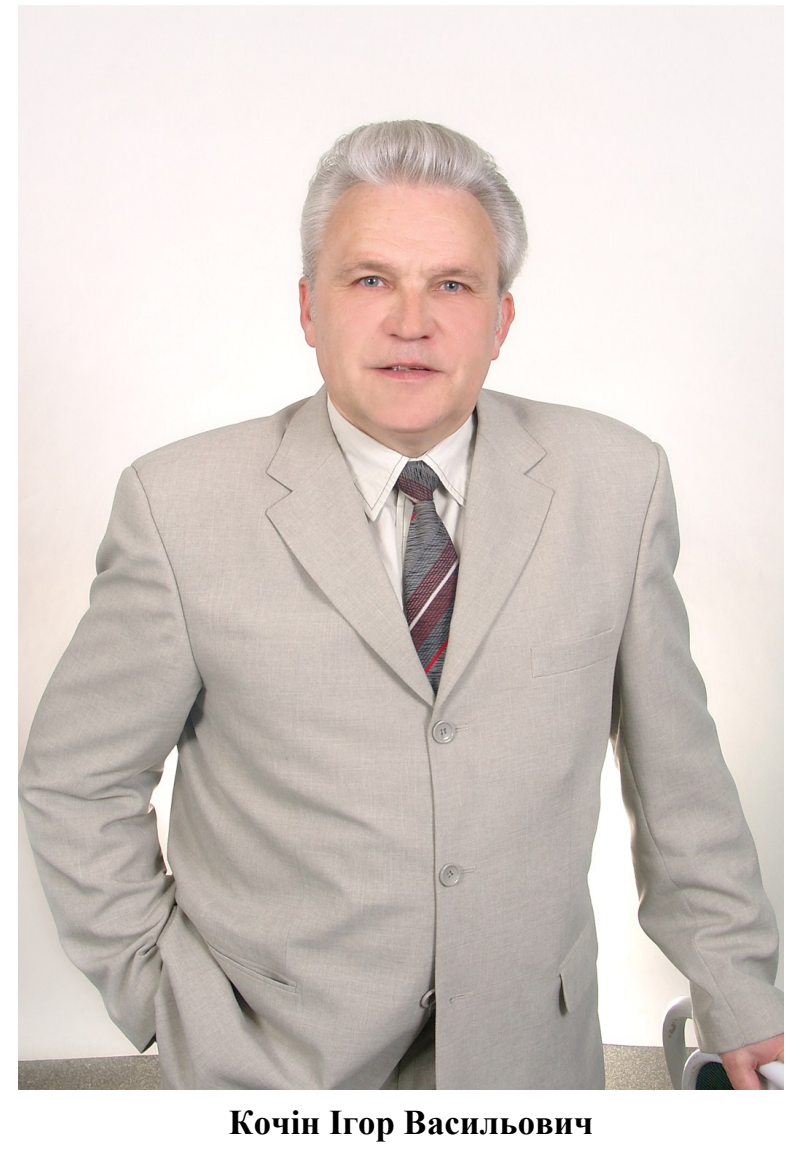

Життя кожної особистості - curriculum vitae (опис життя, біографія), а тим більше знаного вченого, необхідно висвітлювати не тільки за вектором його досягнень у часі, а й розглядати у просторі існування суспільства та наукової сфери.

Родинний початок академіка I. В. Кочіна губиться у сивій давнині минулих часів, у численних поколіннях угро-фінського етносу за батьківським родоводом. Пращури його матері були українськими хліборобами й козаками Великого Лугу та Дикого поля (Campi deserte), півдня України і Таврійських степів із розкішною природою, найродючішими у світі чорноземами, багатющими на флору і фауну, але через постійні ординські навали тут було тяжко й небезпечно жити, займатися господарством та засновувати постійні оселі. Ці землі, острів Хортиця на Дніпрі стали колискою українського козацтва, на яких мешкали та стали козаками пращури академіка I. В. Кочіна - захисники й визволителі, “славні прадіди великі”, гідним наслідувачем й послідовником яких він прагне бути все життя.

Життєвий шлях академіка I. В. Кочіна розпочався у славетному місті Запоріжжі у родині інженераекономіста, ветерана Другої світової війни Василя Івановича Кочіна (1904-1976) та медичного працівника фельдшера Валентини Андронівни Кочіної (Палієнко) (1914-2005) 26 серпня 1945 p. Dos est magna parentum virtus (Доброчесність батьків - великий посаг). Це був визначний рік для всієї світової спільноти - 8 травня 1945 р. завершилася німецько-радянська війна (19411945), а 2 вересня - Друга світова (1939-1945). Такі міжнародні і внутрішньодержавні події передували народженню вченого, вплинули на зміст, політичні, соціально-економічні, духовні та морально-етичні умови життя, формували modus vivendi (спосіб життя) сотень мільйонів громадян радянської імперії. Тому Ігор Васильович належить ще й до такої особливої категорії населення України, як “діти війни”, з усіма наслідками, що випливають з екзистенції цього покоління.

Саме в таких складних й несприятливих умовах академіку I. В. Кочіну довелося жити, вчитися, працювати, займатися науковими дослідженнями, оприлюднювати та доводити їх важливість для суспільства, за- 
хищати дисертаційні і наукові роботи, працювати над створенням та виданням багатьох підручників і навчальних посібників, запроваджувати їх у навчальний процес післядипломної медичної освіти. І. В. Кочін українець за походженням та організатор охорони здоров'я за покликанням. Його не зраджує творча наснага i працездатність, він не перестає вчитися і навчати колег, передає свій багатий досвід, зберігає свою особистість, духовний світ і гарт переконань громадянина нової України. Любить педагогічну діяльність. Вважає свій багаторічний досвід та високий фаховий рівень не як особисте досягнення, а як громадський набуток, який повинен передати молодшим колегам. Протягом двадцяти років (з 1999 р.) є Головою науково-методичної ради 3 питань цивільного захисту та безпеки життєдіяльності населення Запорізької області, яка визнана Мiністерством 3 надзвичайних ситуацій кращою в Україні.

Упродовж 1952-1963 рр. він вчиться у Запорізькій загальноосвітній трудовій політехнічній школі № 65 із виробничим навчанням. Отримав кваліфікацію токаря першого розряду. Під час навчання у школі І. В. Кочін активно займався спортом (спортивною гімнастикою, греко-римською боротьбою, самбо, плаванням, ігровими видами спорту, греблею на байдарках, бальними танцями) та посідав призові місця на змаганнях обласного рівня. Був відмінником з фізичної культури. Крім того, відвідував технічні гуртки, авіамодельний та радіотехнічний, де майстрував діючі моделі літаків, брав участь у змаганнях, виготовляв радіоприймачі.

Проте юнака найбільше вабила медицина з романтизованими літературою та кінострічками образами цивільних і військових лікарів, які перемагають будьяку хворобу, а то й смерть. Визначальний вплив на його професійний вибір мала матір, яка у 1934 р. закінчила Запорізький медичний технікум єдиного диспансеру та отримала кваліфікацію помічника лікаря (фельдшера). Станом на 1963 р. вона мала 30-річний стаж у сфері професійної медицини. Venerari parentes liberos decet (Діти повинні шанувати батьків).

Після закінчення школи І. В. Кочін поїхав до Дніпропетровська вступати у медичний інститут на лікувальний факультет, на який був найбільший конкурс серед усіх факультетів. Тоді у Запоріжжі ще не було медичного інституту. Треба сказати, що Ігор Кочін продемонстрував високий рівень знань із чотирьох профільних вступних предметів, пройшов конкурс і був зарахований до медичного інституту, в якому навчався два роки, а на третій курс був переведений до Запорізького медичного інституту, відкритого у 1964 р.

22 червня 1969 р. I. В. Кочіну було присвоєно кваліфікацію лікаря (спеціальність “Лікувальна справа”). Знаменно, що його курс був першим випуском лікувального факультету Запорізького медичного інституту.

Керівництво навчального закладу, зокрема ректор, доцент I. I. Токаренко, запропонувало молодому спеціалісту залишитися працювати на посаді асистента кафедри соціальної гігієни та організації охорони здоров'я.

28 червня 1969 р. був прийнятий на роботу. Збувалося багаторічне омріяне прагнення займатися науковою і викладацькою діяльністю. Саме так I.В.Кочін уявляв свій життєвий шлях - працювати викладачем в медичному інституті, присвятивши себе улюбленій справі, захистити дисертацію, відбутися як науковцю й далі торувати свій життєвий шлях на педагогічній та науковій ниві. В результаті так і сталося, але у 1973 р. I. В. Кочін через наукові розбіжності був вимушений перейти працювати цеховим лікарем-терапевтом Запорізького коксохімічного заводу спочатку у 10 -й міській лікарні, а з 1974 р. у зв'язку з реорганізацією медикосанітарної допомоги працівникам металургійного комплексу - у медико-санітарній частині комбінату “Запоріжсталь” і заводу “Дніпроспецсталь”. І.В.Кочін наполегливо продовжував займатися науковою роботою, представляти на з'їздах та науково-практичних конференціях результати своїх досліджень, друкувати наукові праці у провідних журналах держави. Під керівництвом завідувача кафедри соціальної гігієни та організації охорони здоров'я Дніпропетровського медичного інституту, заслуженого працівника вищої школи УРСР, д. мед. н., проф. Г. Ф. Смельянової виконав та 20 жовтня 1982 р. у ВНДІ медичної та медико-технічної інформації (голова спеціалізованої вченої ради - проф. Д. Д. Вєнєдіктов, м. Москва) захистив кандидатську дисертацію "Социально-гигиенические аспекты состояния здоровья рабочих некоторых коксохимических предприятий Украины".

У 1983 р. кандидат медичних наук І.В.Кочін був запрошений на науково-педагогічну роботу до Запорізького державного інституту удосконалення лікарів (ЗДІУЛ), в якому почав працювати з 20 червня 1983 р. на посаді старшого викладача кафедри соціальної гігієни та організації охорони здоров'я.

I. В. Кочін завжди цінував родину. 19 жовтня 1984 p. він одружився з Ольгою Григорівною Поцулко. Його дружина за фахом інженер-будівельник.

16 жовтня 1993 р. дійсним членом Української міжнародної академії оригінальних ідей (УМАОІ).

За активну педагогічну, навчально-методичну та наукову роботу, публікацію більше 130 наукових праць у провідних фахових виданнях, принципово нові наукові результати досліджень впливу образу життя на формування стану здоров'я працівників промисловості, успішне завершення докторської дисертації рішенням Вченої ради ЗДІУЛ від 15 листопада 1994 р. Ігорю Васильовичу присвоєне вчене звання доцента.

Під керівництвом наукових консультантів, проф. В. Ф. Посного (м. Запоріжжя) та проф. М. I. Хижняка (м. Київ), І. В. Кочін виконав та 31 жовтня 1996 р. захистив у Національному медичному університеті ім. акад. О.О.Богомольця (голова спеціалізованої вченої ради академік АМН України, проф. С. Г. Гончарук) докторську дисертацію на тему "Наукове обгрунтування соціально-гігієнічних аспектів системи збереження і відтворення стану здоров'я працівників промисловості (на прикладі коксової і хімічної промисловості)". Публічно захищалось 107 надрукованих наукових праць. 16 лютого 2006 р. I.В. Кочіну було присвоєно вчене звання професора.

Проведене ним комплексне дисертаційне дослідження потребувало розробки нових теоретикометодологічних та методичних парадигмальних основ вивчення системи “Образ, спосіб та стиль життя - здоров'я”, що відповідало практичним потребам держави у збереженні та відтворенні стану здоров'я населення й галузі охорони здоров'я як важливої складової у цьому процесі. Загалом цій проблемі академік І. В. Кочін присвятив більше 200 наукових праць, які були високо оцінені й визнані фахівцями та прийняті науковою спіль- 
нотою для подальшого використання у наукових дослідженнях. Учений створив сучасну теорію соціальногігієнічної сфери образу, способу та стилю життя, на основі якої розроблені змістовно взаємопов'язані їх концептуальна, логічна та операціональна моделі. Для опису і пояснення логіки соціальної взаємодії у науковий обіг соціальної гігієни (медицини) та практичного використання у діяльності державної системи забезпечення збереження та відтворення стану здоров'я української нації академік I. В. Кочін увів системну діалектичну тріаду понять - образ, спосіб та стиль життя, які переходять одне в одне і віддзеркалюють діалектику соціальних процесів на різних рівнях узагальнення, розкриваючи їх формуючий вплив на стан здоров'я, а звідси змістовне розуміння механізму формування здорового образу, способу та стилю життя.

У контексті наукових досліджень Ігор Васильович запровадив ідеї і методи математичної теорії планування експерименту для моделювання впливу різноманітних комплексів чинників на формування рівнів захворюваності населення. Він запропонував математикостатистичні способи прогнозування 3 використанням поліноміальних моделей та методи екстраполяційного прогнозування показників стану здоров'я населення та окремих його прошарків, які довели свою доцільність на практиці. Ці наукові розробки стали фундаментальною основою розв'язання проблеми практичного оцінювання образу, способу та стилю життя особи на шкалі “здоровий - нездоровий образ, спосіб і стиль життя”, що сприяло вирішенню давньої проблеми влади та суспільства зі створення, впровадження та прогнозної оцінки ефективності конкретних державних програм, соціальних і медико-соціальних заходів із суттєвого підвищення стану та потенціалу здоров'я населення України через покращення функціонування систем життєзабезпечення, які обумовлюють стан здоров'я, християнське виховання, духовний й морально-етичний рівень суспільства, формування та підтримку здорового способу життя.

На засадах теорії ймовірностей академік I. В. Кочін створив методологію і прикладний метод інтегрального оцінювання стилю життя особи з використанням Байєсівського математичного підходу. Обгрунтована, теоретично і практично реалізована (з використанням інформаційних технологій) математико-статистична процедура інтегрованого оцінювання й розпізнавання образів стилів індивідуальної життєдіяльності та математичний алгоритм їх багатовимірної класифікації з отриманням системи типів стилів життя (типології). Математично доведено об'єктивне існування відмінних якісно та неповторних змістовно особистих стилів життя в кожного індивіда, які й визначають стан і потенціал здоров'я, формують особисту патологію, можливість (ймовірність, ризик) виникнення та фактичне виникнення окремих нозологій у кожної особи. Академік I. В. Кочін довів, що стиль особистого життя регулюється і залежить від власної системи духовно-етичних цінностей, які, своєю чергою, формуються під впливом панівних у державі й суспільстві еталонів моральності і свідомості.

З 12 березня 1998 р. академік І.В.Кочін очолює кафедру медицини катастроф (з 2008 р. - кафедра цивільного захисту та медицини катастроф) Запорізького державного інституту удосконалення лікарів (з 2002 р.
- Запорізька медична академія післядипломної освіти, a 32011 p. - Державний заклад “Запорізька медична академія післядипломної освіти МО3 України”). 3 цього часу основним науковим напрямом його роботи $є$ розробка організаційних та управлінських засад, планування, інформаційного та матеріально-технічного забезпечення діяльності Державної служби медицини катастроф (ДСМК) України, організації надання екстреної медичної допомоги населенню, потерпілому від надзвичайних ситуацій. Так, у наукових працях Ігоря Васильовича міститься велика кількість принципово нових ідей, понять та підходів до розв'язання актуальних проблем науки i предмету викладання медицини катастроф та ДСМК України, які розвиваються науковою школою. Для подальшого удосконалення діяльності ДСМК України розроблені три взаємопов'язані системи організаційних принципів: створення, управління й діяльності служби; добору медичного й немедичного персоналу служби з використанням комплексу психофізіологічних тестів визначення придатності до роботи в екстремальних умовах; організаційних засад медичної евакуації та надання екстреної медичної допомоги у надзвичайних ситуаціях (НС) 3 використанням попередньо виконаних кількох варіантів прогнозних розрахунків на засадах теорії масового обслуговування із застосуванням методу твірних функцій й перетворення Лапласа.

В зв'язку 3 цим наукова робота професорськовикладацького складу кафедри ЦЗ та МК під керівництвом академіка I.В. Кочіна була спрямована на виконання наступних науково-дослідних робіт: “Організація надання екстреної медичної допомоги ураженим сильнодіючими отруйними речовинами (СДОР) в догоспітальному періоді” (1996-1999рр.), “Організація захисту працівників хімічно небезпечного об'єкта при аваріях на ємностях 3 сильнодіючими отруйними речовинами” (2000-2003 рр.), “Організація екстреної медичної допомоги працівникам хімічно небезпечного об'єкту при аваріях на ємкостях 3 хлором" (2004-2006 рр.), “Організація та планування екстреної медичної допомоги Державною службою медицини катастроф територіального рівня працівникам та населенню у разі виникнення осередків ураження при аваріях на хімічно небезпечних об'єктах” (2007-2011рр.), “Удосконалення організації та діяльності Державної служби медицини катастроф України при наданні екстреної медичної допомоги у надзвичайних ситуаціях" (2012-2016рр.), "Удосконалення планування i організації діяльності Служби медицини катастроф з надання екстреної медичної допомоги при надзвичайних ситуаціях мирного та воєнного часу” (2017-2021 рр.).

I. В. Кочін $€$ ініціатором створення нової за змістом та $з$ потенційно більшими інтелектуальними та науково-практично-навчальними можливостями творчо самостійної організаційної структури - "Науководослідний інститут медицини катастроф та екстреної медичної допомоги при надзвичайних ситуаціях" (НДІ МК та ЕМД НС) у складі ДЗ “ЗМАПО МОЗ України”.

31998 р. академік І. В. Кочін створив кілька творчих різних за складом авторських колективів, до яких входять висококваліфіковані фахівці, що займалися підготовкою 39 підручників та навчальних посібників із різних актуальних проблем предметної сфери цивільного захисту та медицини катастроф. На Всеукраїнському конкурсі перший в Україні підручник українською мо- 
вою “Медицина катастроф” був визнаний кращою книгою 2000 р. (наклад перевидано у 2002 р.). За останні роки була видана низка навчальних посібників 3 актуальних, але не представлених у навчальній літературі України, проблем: “Сильнодіючі отруйні речовини: джерела, небезпека, захист" (2002), "Повені і діяльність служби медицини катастроф” (2003), “Землетруси. Характеристика, лікувально-евакуаційне забезпечення” (2004), “Наукові основи епідеміології катастроф” (у двох томах, 2004), “Діяльність Державної служби медицини катастроф у разі ураження населення небезпечними хімічними речовинами" (2005), “Охорона праці та безпека життєдіяльності населення при надзвичайних ситуаціях" (2005), “Медицина катастроф” (2008). Уперше в Україні для фахівців ДСМК видано навчальний посібник “Діяльність Державної служби медицини катастроф України з протидії біологічному, хімічному та ядерному тероризму” (2010), “Основи діяльності Державної санітарно-епідеміологічної служби України в умовах надзвичайних ситуацій та локальних бойових конфліктів" (2015). За цей час авторський колектив підготував низку навчальних посібників, присвячених радіаційним аваріям, організації захисту та надання медичної допомоги при них, фаховій підготовці формувань ДСМК.

I. В. Кочін $\epsilon$ автором більше 800 наукових праць.

Також I. В. Кочін проводить велику роботу з розбудови козацтва України. Велика Козацька Рада Війська Запорозького Низового доводить до відома: "Ми, козаки, лицарі Славного Війська Запорозького, оголошуємо всім і кожному особливо через нашу родову козацьку грамоту: Хрещенська Велика Козацька Рада Міжнародного союзу козаків “Запорозька Січ” своїм рішенням від 19 січня 2002 p. за особливі заслуги в справі розвитку Запорозького Козацтва вводить Кочіна Ігоря Васильовича та його нащадків на вічні часи на честь і гідність запорозького козака; також він та його рід вноситься до списку Родової книги Міжнародного союзу козаків “Запорозька Січ”, в доказ чого видається ця грамота”. Покровська Велика Козацька Рада Війська Запорозького Низового своїм рішенням присвоїла І. В. Кочіну звання полковника.
14 жовтня 2005 р. йому був вручений корпоративний знак Запорізького козацького округу. 14 лютого 2007 р. Ігор Васильович удостоєний почесного козацького хреста “За віру та волю”. У 2006 р. заступник отамана з роботи 3 особовим складом Спілки громадських організацій “Запорозький козацький округ”, генерал-хорунжий Війська Запорозького Низового I. В. Кочін був нагороджений за відданість справі Запорозького козацтва медаллю “Козацька звитяга". Є стійким і послідовним прихильником реалізації національної ідеї - розбудови самостійної, політично і економічно незалежної України, заможного життя українського народу.

Antoniy Moysey. One of people, who is fond of science and educational activities: dedicated material to the 75-annivesary of Kochin Igor Vasylyovych. The article highlights the biographical milestones and scientific achievements of a famous Ukrainian scientist, head of the Department of Civil Protection and Disaster Medicine of State Institute «Zaporizhzhia Medical Academy of Postgraduate Education of Ministry of Health of Ukraine», Academician of the Ukrainian International Academy of Original Ideas, Doctor of Medical Science, Doctor of Philosophy, professor, Chairman of the Scientific and Methodological Council on civil protection and life safety of Zaporozhye region, Ataman's Deputy of Nongovernmental organizations «Zaporozhye Cossacks District», General-horunzhy of «Zaporozhian Host».

Key words: Igor V. Kochin, Zaporizhzhya Medical Academy of Postgraduate Education of Ministry of Health of Ukraine, biographical study.

Мойсей Антоній - доктор історичних наук, професор, завідувач кафедри суспільних наук та украӥнознавства ВДНЗ Украӥни «Буковинський державний медичний університет».

Moysey Antoniy - Doctor of Historical Sciences, Prof., Chief of the Social Sciences and Ukrainian Studies in Higher State Educational Establishment of Ukraine «Bukovinian State Medical University».

Received: 17.10.2019

Advance Access Published: December, 2019

(C) A. Moysey, 2019

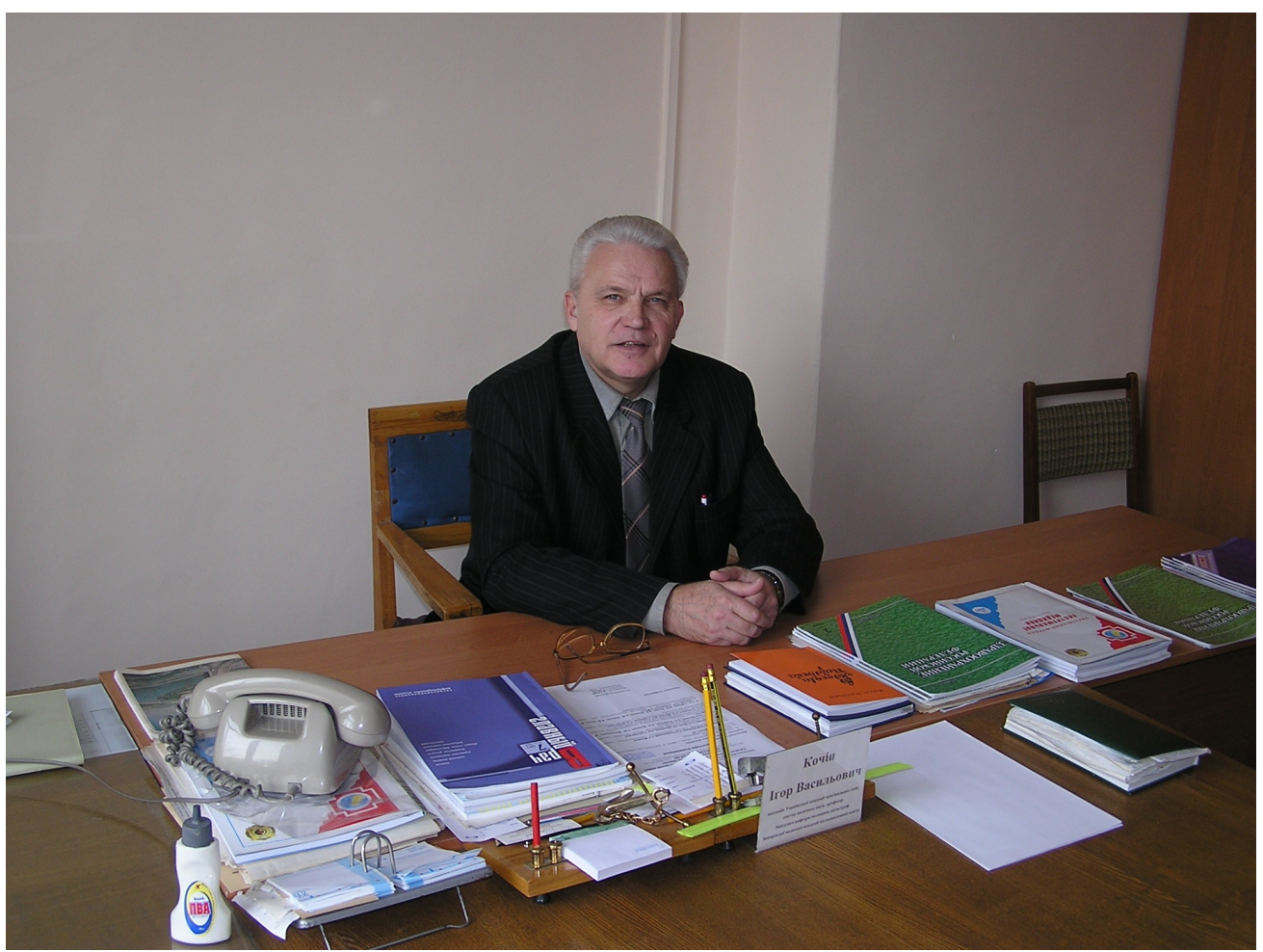

Кочін Ігор Васильович 


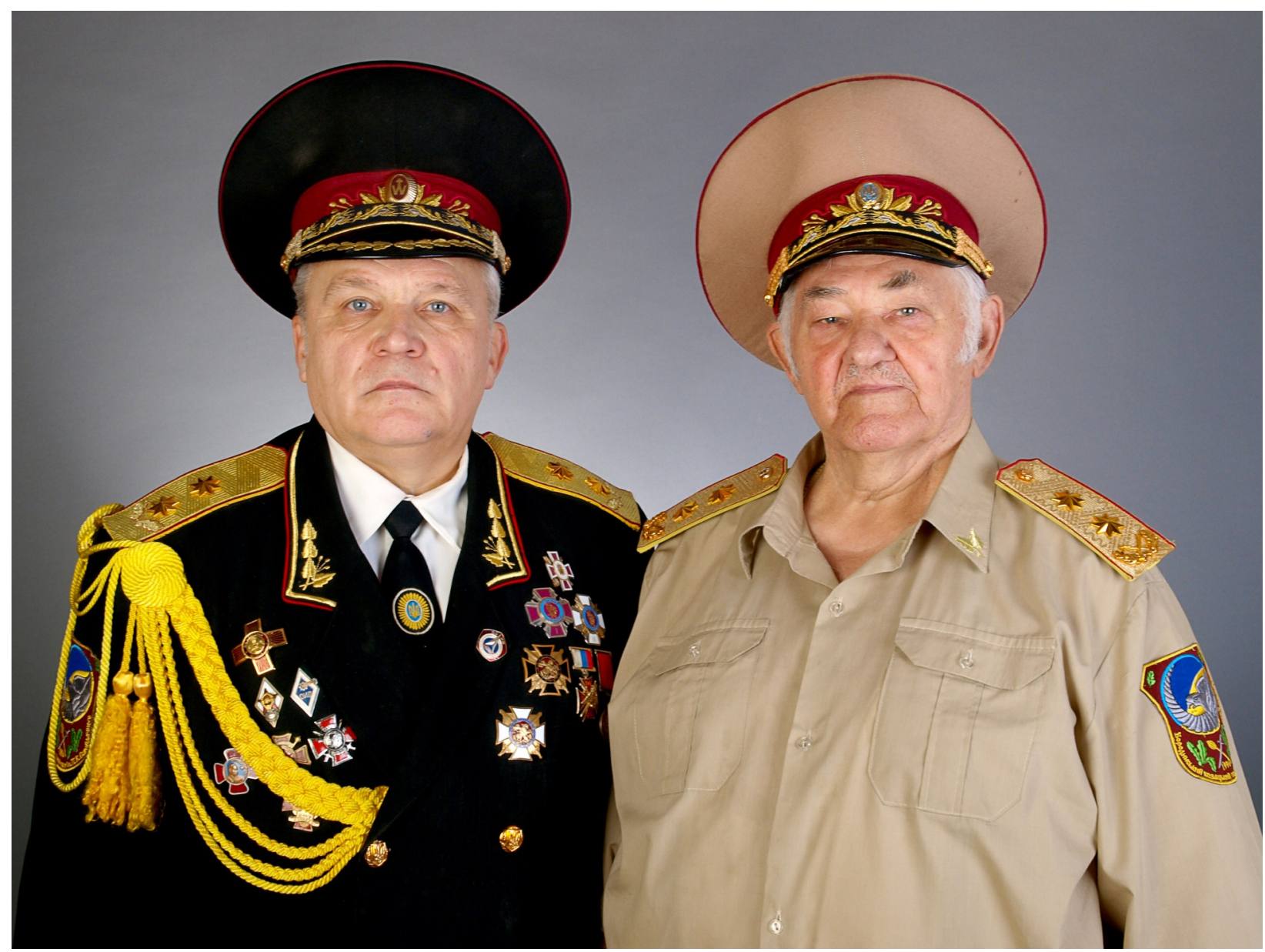

Кочін Ігор Васильович - генерал-хорунжий Війська Запорозького Низового, Заступник отамана Спілки громадських організацій «Запорозький козацький округ» (зліва) та Гладкий Едуард Олександрович генерал-хорунжий Війська Запорозького Низового, отаман Спілки громадських організацій «Запорозький козацький округ»

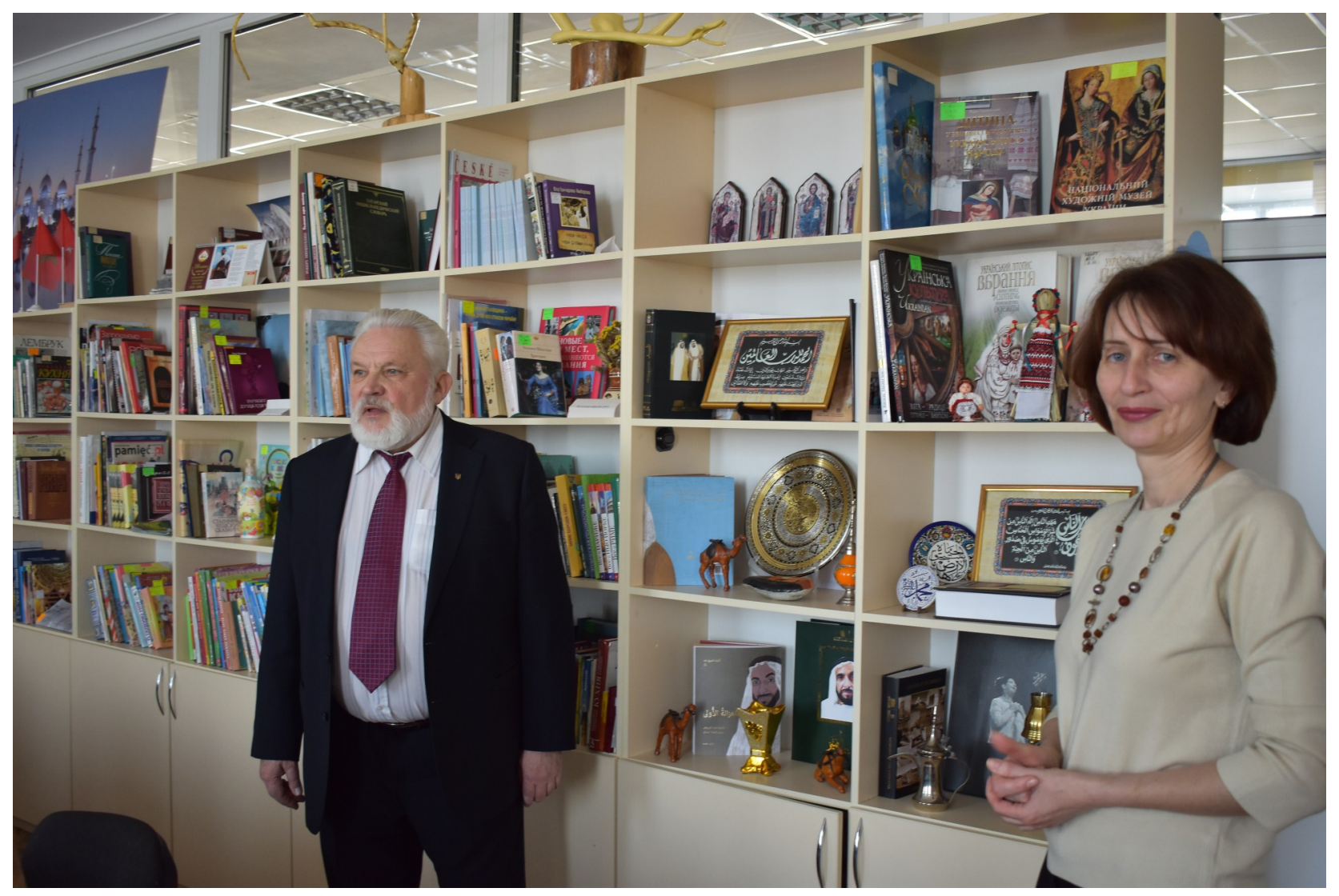

